\title{
PENGARUH FAKTOR KERAWANAN PANGAN DAN LINGKUNGAN TERHADAP STUNTING
}

\author{
Aris Widiyanto ${ }^{1}$, Joko Tri Atmojo ${ }^{1}$, Aquartuti Tri Darmayanti² \\ ${ }^{1}$ Sekolah Tinggi Ilmu Kesehatan Mamba'ul 'Ulum, Surakarta \\ ${ }^{2}$ Program Magister Kesehatan Masyarakat, Universitas Sebelas Maret
}

\begin{abstract}
Background: Globally, it is estimated that one in five children will fail to grow or be known as stunting in 2020. In Indonesia based on Nutritional Status Monitoring (PSG) data for the past three years. The prevalence of short-term toddlers has increased from 2016 at 27.5\% to 29.6\% in 2017. Method: The interaction between environment and nutrition, especially food insecurity presents interesting dynamics that can be studied further. In this review the authors are interested in providing scientific evidence-based information about the effects of food and environmental vulnerability factors on the incidence of stunting. Search for published articles is done through databases: PubMed, EMBASE, Scopus, CINAHL (EBSCO), the official website of national health organizations, online libraries, and the UNICEF library from February 10 to March 25, 201. Result: Stunting AND Risk Factors, Factors affecting stunting, Stunting AND food insecurence, stunting AND environment factors, Stunting AND Indonesia. Inclusion criteria were systematic reviews, clinical reviews, cohort studies, cross-sectional studies, clinical studies, health reports and program guidelines. Conclusion: Factors influencing stunting including: food insecurity increases the risk of stunting (OR $=1.17$ 95\% CI: 1.09-1.25) and less weight $(O R=1.1795 \%$ CI: 1.01-1.36). lack of sanitation, flooring type and mycotoxin exposure in the form of AF-alb.
\end{abstract}

Keywords: Stunting, Risk Factors, Food Insecurity

\section{PENDAHULUAN}

Secara Global, diperkirakan satu dari lima anak akan mengalami kegagalan untuk tumbuh atau dikenal sebagai stunting pada tahun 2020 (De Onis et al., 2012). Prevalensi stunting turun dari 29,5 persen menjadi 22,9 persen antara 2005 dan 2016, meskipun 155 juta anak balita di seluruh dunia masih menderita stunting. Pada tahun 2016 diperkirakan jumlah orang yang kekurangan gizi kronis di dunia telah meningkat menjadi 815 juta, naik dari 777 juta pada 2015 meskipun masih turun dari sekitar 900 juta pada tahun 2000 (FAO, IFAD and WFP, 2017).
Stunting adalah istilah yang diberikan untuk gangguan pertumbuhan linear (panjang / tinggi berdasarkan usia) pada tahun-tahun awal kehidupan, hal ini mengakibatkan kegagalan mencapai ketinggian saat dewasa yang disiratkan oleh potensi genetik (WHO/UNICEF 2012; Vilcins et al., 2018).

Di Indonesia berdasarkan data Pemantauan Status Gizi (PSG) selama tiga tahun terakhir, stunting memiliki prevalensi tertinggi dibandingkan dengan masalah gizi lainnya seperti gizi kurang, kurus, dan gemuk. Prevalensi balita pendek mengalami peningkatan dari tahun 2016 yaitu $27,5 \%$ menjadi $29,6 \%$ pada 
tahun 2017 (Joint Child Malnutrition Eltimates, 2018).

Stunting (kerdil) adalah kondisi dimana balita memiliki panjang atau tinggi badan yang kurang jika dibandingkan dengan umur. Kondisi ini diukur dengan panjang atau tinggi badan yang lebih dari minus dua standar deviasi median standar pertumbuhan anak dari WHO (Joint Child Malnutrition Eltimates, 2018).

Stunting dapat menghasilkan efek kesehatan negatif seperti kesulitan dalam mencapai perkembangan fisik dan kognitif yang optimal, mengurangi kinerja dan beberapa studi juga melaporkan peningkatan risiko penyakit kronis tidak menular (Uauy et al., 2011; Joint Child Malnutrition Eltimates, 2018;Dewey and Begum, 2011).

Penelitian tentang stunting banyak berfokus pada asupan makanan, namun semakin banyak bukti telah menunjukkan peran penting lingkungan alami dan fisik. Interaksi antara lingkungan dan nutrisi terutama kerawanan pangan menghadirkan dinamika yang menarik yang dapat dikaji lebih jauh. Namun demikian tetap tidak mengabaikan berbagai faktor lain dalam kejadian stunting.

Pada tinjauan kali ini penulis tertarik untuk memberikan informasi berbasis bukti ilmiah tentang pengaruh faktor kerawanan pangan dan lingkungan terhadap kejadian stunting.

\section{METODE PENELITIAN}

Pencarian sistematis dilakukan untuk artikel sains yang dipublikasikan melalui database antara lain: PubMed, EMBASE, Scopus, dan CINAHL (EBSCO) dari 10 Februari hingga 25 maret 2019. Pencarian literatur berupa laporan resmi juga dilakukan menggunakan situs organisasi kesehatan dunia, situs resmi organisasi kesehatan nasional, Perpustakaan online, dan perpustakaan UNICEF,

Kata kunci yang digunakan antara lain: stunting AND Risk Factors, Faktor yang mempengaruhi stunting, Stunting AND food insecurence, stunting AND environment factors, Stunting AND Indonesia.

\section{Kriteria inklusi}

Kriteria inklusi adalah tinjauan sistematis, tinjauan klinis, studi kohort, studi cross-sectional, studi klinis, laporan kesehatan dan pedoman program.

\section{HASIL PENELITIAN}

Setelah memeriksa artikel teks lengkap dengan seksama, akhirnya 19 artikel dimasukkan untuk dibahas lebih lanjut dengan berbagai faktor antara lain:

1. Kerawanan Pangan dan Stunting Kerawanan pangan didefinisikan sebagai "ketersediaan nutrisi yang terbatas atau tidak pasti definisi lain menyebutkan kerawanan pangan adalah kemampuan terbatas atau tidak pasti untuk memperoleh makanan yang aman dan dapat diterima secara sosial " (Arab et al., 2018).

Kerawanan pangan mempengaruhi kesehatan dan kesejahteraan sepanjang hidup, dari periode prenatal dan memiliki peran sangat penting bagi anak-anak, karena kandungan gizi dari makanan mereka tidak hanya mempengaruhi kesehatan mereka saat ini, tetapi juga perkembangan fisik, mental, dan sosial (Cook and Frank, 2008; Arab et al., 2018).

Kerawanan pangan yang terjadi pada masa anak-anak memiliki efek 
jangka panjang pada perkembangan kognitif, sosial-emosional, dan pada akhirnya mengganggu prestasi akademik bahkan apabila kerawanan pangan telah teratasi 3 tahun sebelumnya (Howard, 2011).

Studi meta analisis yang dilakukan (Arab et al., 2018) memberikan hasil bahwa kerawanan pangan meningkatkan risiko stunting (OR $=1,17$ 95\% CI:1.091.25) dan berat badan kurang $(\mathrm{OR}=1.17$ 95\% CI: 1.01-1.36). Analisis subkelompok berdasarkan usia menunjukkan bahwa kerawanan pangan meningkatkan risiko pertumbuhan terhambat $(\mathrm{OR}=1,20$ 95\% CI: $1,02-1,39)$ untuk anak-anak di atas 5 tahun. Asosiasi ini signifikan hanya untuk risiko stunting $(\mathrm{OR}=1,14$

95\% CI: 1,05-1,23) pada anak di bawah 5 tahun.

Selanjutnya, analisis subkelompok berdasarkan tingkat perkembangan negara mengimplikasikan bahwa anak-anak dan remaja yang tinggal di negara berkembang memiliki risiko stunting yang lebih tinggi $(\mathrm{OR}=1,16$ 95\% CI: 1,05-1,27) dibanding anak-anak yang tinggal dinegara maju.

2. Faktor Lingkungan dan stunting

Beberapa faktor lingkungan yang telah terbukti dapat mengakibatkan stunting antara lain:

a. Sanitasi

Akses ke sanitasi yang lebih baik dapat melindungi anak dari kejadian stunting sekitar 70,6\% (Folake, Cole and OldewageTheron, 2008; Fenske et al., 2013) penelitian lain dengan sample yang lebih besar menggunakan variabel kepemilikan jamban pribadi menunjukan bahwa apabila akses ke jamban meningkat maka kejadian stunting akan menurun (sebagian besar studi dilakukan di desa) (Silveira et al., 2010). Studi lain menemukan bukti pengurangan kebiasaan buag air besar sembarangan di sebuah desa lebih efektif dalam mengurangi stunting daripada meningkatkan kepemilikan jamban pribadi (Spears, 2013).

b. Akses air bersih

Banyak studi yang menganalisis hubungan akses terhadap air bersih dengan kejadian stunting, namun berdasarkan 33 studi multinasional yang dilakukan (Vilcins, Sly and Jagals, 2018) Hanya 48\% (16/33) studi yang berpendapat akses ke sumber air bersih dapat menurunkan kejadian stunting, dan terdapat $52 \%(17 / 33)$ dari studi tidak menemukan hubungan antara keduanya. Kurangnya konsensus, uji klinis acak (randomizzed controlled trials), dan juga kurangnya studi untuk menguji kualitas dan keamanan air, atau mengomentari efek musiman pada keamanan air di antara studi ini menunjukkan bahwa akses ke air bersih dan kejadian stunting masih belum bisa dikonfirmasi (Fink, Günther and Hill, 2011).

c. Rumah tinggal

Terbuat dari bahan apa sebuah rumah dibangun ternyata mempengaruhi kesehatan anak terutama stunting. Lantai rumah yang terbuat dari tanah dapat meningkatkan kejadian stunting (Vilcins, Sly and Jagals, 2018). Penelitian yang dilakukan oleh (Chopra, 2003; Folake et al., 2008;El Taguri et al., 2009; Silveira et al., 2010) melaporkan 
bahwa lantai tanah dapat meningkatkan kejadian stunting dikarenakan

anak-anak yang tinggal di rumah dengan lantai tanah dapat terserang penyakit yang menjadi salah satu faktor pemicu stunting Sebagai contoh, penyakit Chagas adalah penyakit endemik di Amerika selatan dan mungkin menjadi agen penyebab kejadian stnting.

3. Paparan agen mikotoksin

Studi menunjukkan bahwa kadar AF-alb (aflatoxin-albumin) yang lebih tinggi dalam serum,

Merupakan biomarker untuk paparan aflatoksin (mikotoksin) dan terkait dengan stunting.

Hubungan terbalik juga dilaporkan antara Skor-Z untuk tinggi berdasarkan usia dengan paparan aflatoksin B1. Jika paparan AF-alb B1 tinggi maka skor $\mathrm{Z}$ menurun (Shouman $e t$ al., 2012).

Aflatoksin adalah hasil metabolit dari beberapa spesies jamur Aspergillus dan merupakan mikotoksin hepatotoksik dan hepatokarsinogenik yang paling kuat. Aflatoksikosis akut menyebabkan penyakit dan kematian pada manusia. Aflatoksin serum juga merupakan faktor risiko untuk penyakit kuning neonatal dan morbiditas pada bayi, infertilitas, dan malnutrisi (Obuseh et al., 2010).

\section{PEMBAHASAN}

Dalam ulasan ini beberapa faktor risiko baik dari pangan, lingkungan, dan paparan agen biologis telah dipelajari terkait hubungannya dengan stunting. Kami menemukan bahwa kerawanan pangan, kekurangan sanitasi, lantai tanah dan paparan mikotoksin dalam makanan meiliki asosiasi dengan kejadian stunting.
Sebaliknya, kurangnya mengakses air bersih belum dapat disimpulkan sebagai faktor risiko yang secara mandiri menyebabkan kejadian stunting.

Langkah yang strategis daam penanggulangan stunting perlu dilakukan, salah satu yang telah dilakukan oleh pemerintah Indonesia terkait menurunkan faktor risiko diatas adalah "intervensi Gizi' berupa langkah intervensi gizi sensitif dan intervensi gizi spesifik. (Joint Child Malnutrition Eltimates, 2018).

Intervensi gizi spesifik lebih ditujukan pada upaya menangani penyebab langsung masalah gizi (asupan makan dan penyakit infeksi) dan berada dalam lingkup kebijakan kesehatan. Melalui intervensi spesifik, sekitar 15\% kematian anak balita dapat dikurangi bila intervensi berbasis bukti tersebut dapat ditingkatkan hingga cakupannya mencapai $90 \%$, termasuk stunting yang dapat diturunkan sekitar 20,3\%.

Intervensi gizi sensitif ditujukan untuk mengatasi penyebab tidak langsung yang mendasari terjadinya masalah gizi (ketahanan pangan, akses pelayanan kesehatan, kesehatan lingkungan, serta pola asuh) dan terkait dengan kebijakan yang lebih luas tidak terbatas bidang kesehatan saja tetapi juga pertanian, pendidikan, hygiene air dan sanitasi, perlindungan sosial, dan pemberdayaan perempuan. Program dan kebijakan gizi sensitif ini memiliki kontribusi yang cukup besar untuk mendukung pencapaian target perbaikan gizi meskipun secara tidak langsung.

\section{KESIMPULAN DAN SARAN}

Stunting merupakan kejadian yang dipengaruhi oleh berbagai faktor, beberapa faktor yang telah banyak diteliti dan terbukti meningkatkan stunting adalah 
kerawanan pangan, kekurangan sanitasi, lantai tanah dan paparan mikotoksin.

Indonesia telah menerapkan intervensi gizi sebagai upaya untuk mengantisipasi dan mengkoreksi faktor resiko tersebut, intervensi yang berfokus pada penyebab langsung adalah intervensi gizi spesifik, sedangkan Intervensi gizi sensitif ditujukan untuk mengatasi penyebab tidak langsung yang mendasari terjadinya masalah gizi.

\section{DAFTAR RUJUKAN}

Arab, A. et al. (2018) 'Food Insecurity and the Risks of Under-nutrition Complications among Children and Adolescents: A Systematic Review and Meta-Analysis', Nutrition. Elsevier Inc.

B.O., S. et al. (2012) 'Aflatoxin B1 level in relation to child's feeding and growth', Indian Journal of Pediatrics.

Chopra, M. (2003) 'Risk factors for undernutrition of young children in a rural area of South Africa', Public Health Nutrition.

Cook, J. T. and Frank, D. A. (2008) 'Food security, poverty, and human development in the United States', Annals of the New York Academy of Sciences.

Dewey, K. G. and Begum, K. (2011) 'Long-term consequences of stunting in early life', Maternal and Child Nutrition. doi: 10.1111/j.17408709.2011.00349.x.

FAO, F. and A. O. of the U. N., IFAD, I. F. for A. D. and WFP, W. F. P. (2015) 'The State of Food Insecurity in the World', in International Hunger Targets: taking stock of uneven progress.
Fenske, N. et al. (2013) 'Understanding child stunting in India: A comprehensive analysis of socioeconomic, nutritional and environmental determinants using additive quantile regression', $P L O S$ ONE.

Fink, G., Günther, I. and Hill, K. (2011) 'The effect of water and sanitation on child health: Evidence from the demographic and health surveys 1986-2007', International Journal of Epidemiology..

Folake, O. S., Cole, A. H. and OldewageTheron, W. H. (2008) 'Undernutrition and household environmental quality among urban and rural children in Nigeria', Pakistan Journal of Nutrition.

Howard, L. L. (2011) 'Does food insecurity at home affect noncognitive performance at school? A longitudinal analysis of elementary student classroom behavior', Economics of Education Review.

Joint Child Malnutrition Eltimates (2018) 'Buletin Stunting', Journal of Molecular Biology, 301(5), pp. 1163-1178.

Obuseh, F. A. et al. (2010) 'Aflatoxin B 1 albumin adducts in plasma and aflatoxin $\mathrm{M} 1$ in urine are associated with plasma concentrations of vitamins $\mathrm{A}$ and E', International Journal for Vitamin and Nutrition Research, 80(6), pp. 355-368.

De Onis, M., Blössner, M. and Borghi, E. (2012) 'Prevalence and trends of stunting among pre-school children, 1990-2020', Public Health Nutrition. 
Silveira, K. B. R. et al. (2010) 'Association between malnutrition in children living in favelas, maternal nutritional status, and environmental factors', Jornal de pediatria.

Spears, D. (2013) How Much International Variation in Child Height Can Sanitation Explain?, World Bank Policy Research Working Paper.

El Taguri, A. et al. (2009) 'Risk factors for stunting among under-fives in Libya', Public Health Nutrition.

Uauy, R., Kain, J. and Corvalan, C. (2011) 'How can the Developmental Origins of Health and Disease (DOHaD) hypothesis contribute to improving health in developing countries?', in American Journal of Clinical Nutrition.

Vilcins, D., Sly, P. D. and Jagals, P. (2018) 'Environmental Risk Factors Associated with Child Stunting: A Systematic Review of the Literature', Annals of Global Health, 84(4), p. 551.

WHO/UNICEF Joint Monitoring Programme for Water Supply and Sanitation (2012) Progress on Drinking Water and Sanitation, Update. 